\title{
THREE HIDDEN PROBLEMS FACED BY SECOND YEAR UNIVERSITY STUDENTS ON LISTENING SKILL
}

\author{
${ }^{1}$ Novika, H. ${ }^{2}$ Arbain, M. ${ }^{3}$ Aprizani, Y. \\ Islamic University of Kalimantan \\ Hartatya_Novika@yahoo.com
}

\begin{abstract}
This research is aimed at identifying the second-year university students' perspective on the problems encountered in listening comprehension particularly dealing with listening task, effect of the problem and context. The design employed in this research belongs to descriptive research. 50 second-year university students were selected voluntarily. The research result showed problematic uses in which EFL learners have difficulties understanding listening text while the native speakers with varied and non-familiar accents. Besides, they were not able to understand meanings which are not pronounced clearly.
\end{abstract}

Key words: Listening, Listening Problems, Listening Comprehension.

\section{INTRODUCTION}

The last two decades have brought English language teaching and learning to a wide range of audio-visual technologies. The result is that learners can now interact with textual, aural, and visual media in a wide range of formats. Consequently, it is not surprising that teaching English as a foreign language (TEFL) has become very popular during the last century and the foundations have been set to this discipline.

Listening has an important place in learning as it is one of the four major skills in language acquisition. Therefore, it is required to master those four language skills for EFL learners, one of which is listening. Listening is viewed highly necessary for an efficient language learner to master as other three essential language skills (reading, writing, listening and speaking) to be accepted (Yildirim, 2013).

As the very basic language skill, listening, which is consistently integrated with the other language skills (speaking, reading and writing), plays a key role in facilitating language learning. It could be a linguistic and prime skill among the four language skills, 


\section{INTENSIVE JOURNAL \\ http://ojs.uniska-bjm.ac.id/index.php/EJB \\ E-ISSN 2620-4746 \\ April 2020, Vol 3 No.1}

especially in learning a language for communicative purpose. Listening, according to Croom (1998) is viewed plays a vital role, as it helps the language learner to acquire pronunciation, word stress, vocabulary, and syntax and the comprehension of messages conveyed can be based solely on tone of voice, pitch and accent; and it is only possible when we listen. Different from speaking and writing belonging to productive skill, listening belongs to receptive skill, just like reading. Without understanding input appropriately, learning simply cannot get any improvement. In addition, without listening skill, no communication can be achieved. Thus teaching listening is the starting point in teaching English as a foreign language. It is one the basics for establishing good knowledge for communication. It is also the first skill that deals with child learning acquisition, so the child can begin their external relations through listening. The previous research, as done by Gilman and Moody 1984:331 and cited by Rivers (1984), has illustrated that adults spend $40-50 \%$ of communication time listening, $25-30 \%$ speaking, $11-16 \%$ reading, and about $9 \%$ writing.

Listening comprehension could be a linguistic and prime skill among the four language skills (listening, reading, writing, and speaking). Thus, teaching listening is considered the starting point in teaching English as a foreign language. It is not only one of the basics for establishing good knowledge for communication but it is also the first skill that deals with child learning acquisition, through which the child can begin their external relations.

Listening is considered a concept that is both complicated and hard to be analyzed. It means that making a clear and quick definition of listening is difficult (Hichem, 2013). It is almost in line with was stated by Field, (2008b) and Graham \& Macaro, (2008) that listening is one of the most difficult skills for foreign language learners due to the complexity of its process and different types of knowledge required for successful listening. Meanwhile, Vandergrift (1999) viewed listening as a complex, active process in which the listener must discriminate between sounds, understand vocabulary and grammatical structures, interpret stress and intonation, retain what was gathered in all of the above, and interpret it within the immediate as well as the larger socio-cultural context 


\section{INTENSIVE JOURNAL \\ http://ojs.uniska-bjm.ac.id/index.php/EJB \\ E-ISSN 2620-4746 \\ April 2020, Vol 3 No.1}

of the utterance. However, according to Andrade (2006), listening can be referred as one of the four key skills through which a language is taught and it is one of the two language skills that is employed when communicating orally. Besides, listening as a pedagogical term refers to 'speech recognition', 'speech perception', 'speech understanding' and 'spoken language understanding"' (Huei-Chun, 1998). That listening is a very active process means that when we listen not only we deal with whatwe listen or hear but also we combine it with other information that is already familiar. However, Lieu (Huei-Chun, 1998) viewed EFL listening skill has been ignored for a long time that listening is learnt automatically and once for all. It is not surprising that many people, as Solak and Altay just like many other researchers (2014) called the term, have named listening skill as the 'Cinderella Skill' which is disregarded by its big sister speaking skill in language learning. As a consequence, according to Helgesen (2003), by means of this active process, the meaning is created by integrating what is heard or experienced with the data in one has in mind. Tyagi (2013) stated that listening process takes place in five stages of hearing, understanding, remembering, evaluating, and responding.

Tyagi (2013) defines hearing as the perception of sound waves; you must initially hear to listen, but you don't need to listen in order to hear, understanding as the comprehension of symbols we have seen and heard, we must examine the meaning of the stimuli we have perceived, remembering means that a person has not only received and clarified a message but has also added it to the brain's stockpile, evaluating necessitates the active listener to weigh evidence or sort fact from opinion, and specify the presence or absence of bias in a message, and responding requires that the receiver completes the process by means of verbal or nonverbal feedback.

EFL listening skill is considered as a problematic language skill especially in a foreign language context where real practice chances are narrow (Nowrouzi, Tam, Zareian and Nimehchisalem, 2015). Teaching students listening skill may be difficult not only for teachers to teach but for students to learn as well. For instance, even the students who are adequate in speaking and reading might confront problems with listening skill when facing a record with a quick conversation (Ghaderpanahi, 2012). 


\section{INTENSIVE JOURNAL \\ http://ojs.uniska-bjm.ac.id/index.php/EJB \\ E-ISSN 2620-4746 \\ April 2020, Vol 3 No.1}

Many students rely passively on teachers' instruction and seldom realize that they themselves must be active in their listening and learning to listen (Chen, 2010; Goh \& Taib, 2006; Vandergrift, 2003).

In the EFL learners' perspectives, the main problems commonly encountered EFL listening course deals with 1) task, 2) affect and 3) context. It must be admitted that English is the most studied foreign language in Indonesia. It could be said that there is no other foreign language being able to compete with English language. Before entering a university, students have learnt English for 3 years in elementary school; for 3 years in junior school and also 3 years in high school. The main focus of the English courses which the Indonesian students tend to practice is on language structures, reading comprehension, vocabulary and writing. Unfortunately, teaching EFL listening to Indonesian learners is not really easy. Listening skill seems to be ignored in the English program and it seems to continue until university. Consequently, when these students unexpectedly face with more developed or complex listening courses or audio listening tools at universities, they find themselves in a big trouble before they form the needed listening skills. Therefore, this paper is intended to analyze the listening problems of a group of university students studying elementary level - EFL courses at Islamic University of Kalimantan. Ulum (2015) in his recent research found that there have been at least six crucial problems faced by students in EFL listening courses, all of which is concerned with the task, listening process, listener, input, effect and context.

Based on the research background described above, the following research question is as follow: What are the problems faced by the elementary level university students in EFL listening courses in terms of the criteria of (a) task, (b) effect and (c) context? Thus, this descriptive research is aimed at investigating the problems faced by the elementary level university students in EFL listening courses in terms of the following criteria of (a) task, (b) effect and (c) context. 


\section{INTENSIVE JOURNAL \\ http://ojs.uniska-bjm.ac.id/index.php/EJB \\ E-ISSN 2620-4746 \\ April 2020, Vol 3 No.1}

\section{REVIEW OF LITERATURE}

The importance of listening skill in EFL learning is undeniable since the elixir of acquiring a language is to gain language input (Hamouda, 2013). When we process and decode auditory input, it necessitates knowledge of perception. However, when we encode and generate speech output, it necessitates retrieval knowledge (Vandergrift, 1999). Listening comprehension is an immensely integrative skill and it plays a vital role in the process of language learning, promoting the rise of other language skills. As a result, consciousness and formation of proper listening comprehension strategies can aid learners to benefit from the language input they are receiving, Vandergrift (1999) clearly mentions. It is a fact that listening is highly necessary in language learning in that it supplies the learner with the required input and learners can't acquire anything without the comprehension of the specific input (Hamouda, 2013). To gain much authentic input of the target language, students can listen to songs, radio channels or watch any video in the target language; however learning may not be achieved totally as sometimes instructions aren't presented appropriately by the materials (Dey, 2014). Teachers won't present brilliant listening classes if there aren't proper elements such as appropriate apparatus, classroom setting and students' motivation and interest. However, it must be recalled that even if the gears are sufficient it is necessary to have entry into listening materials opted according to the grades and needs of the students as well (Andrade, 2006).

Nowrouzi and others (2015) in their study, have found out that distraction and missing sounds or words linked to perception, chunking complications and sentence dismissing from mind in the process of analysis, also bewilderment about the main idea related to utilization are the first coming problems in listening comprehension activities. EFL listening has always been an ignored skill in both research and practice when compared to reading skill; it is clear that listening is weaker in literature when compared to that of reading comprehension (Nunan, 1997).

A wide variety of problems may be encountered by second or foreign language learners in listening comprehension. Different researchers have focused on various problems and shown a wide range of listening challenges for foreign or second language learners (Goh, 2000; Liu, 2002). Listening comprehension problems refer to all the 


\section{INTENSIVE JOURNAL \\ http://ojs.uniska-bjm.ac.id/index.php/EJB \\ E-ISSN 2620-4746 \\ April 2020, Vol 3 No.1}

difficulties that may occur during the three phases of perception, parsing, and utilization (Anderson, 1995; Goh, 2000, Vandergrift, 2003). Figure 1 presents the three phases in which listening problems can be categorized. As the figure shows, these phases are nonlinear and inter-related. Due to the nature of listening, a listener may have to move focus from one phase to another in order to be able to decode the message.

Al-Thiyabi, his study (2014) formed a need analysis for EFL listening being intended

O to identify different accents and pronunciation due to the variety of students' teachers' background,

○ to identify lengthy description in English and instructions as well,

o to learn and use new and different vocabularies and terminologies that are related to different areas,

o to learn how to take effective notes and how to ask for repetition or clarification in English,

○ to recognize the subject matter of a talk.

Moreover, Al-Thiyabi (2014) puts forward some frequent problems of learners as well as reasons blocking their listening comprehension skill such as hasty speaking, unknown words and weird pronunciation, adding that such problems are severe and ought to be overcome to enhance learner's listening competency level. Bennui (2007) viewed students' prior knowledge of the second or foreign language, motivation and learning strategies, the teachers' teaching methods, classroom environment and facilities all form the most crucial parts of the students' views about the origins of their low listening comprehension performance. It is crucial that EFL instructors boost learners' employment of strategies like individual knowledge and mental translation (Al-Alwan, Asassfeh and Al-Shboul, 2013). According to Tyagi (2013) listening skill contains some essential elements such as:

- connecting linguistic cues to non-linguistic and paralinguistic cues,

$\circ$ discriminating between sounds,

o identifying expressions and sets of utterances that act to create meaning,

○ identifying grammatical groupings of words,

o recalling important words and ideas,

- recognizing words and understanding their meaning, and

$\circ$ using background knowledge to predict and to confirm meaning. 


\section{INTENSIVE JOURNAL \\ http://ojs.uniska-bjm.ac.id/index.php/EJB \\ E-ISSN 2620-4746 \\ April 2020, Vol 3 No.1}

Osuka (2008) in her study found out that the most outstanding element that hinders Japanese EFL students' listening comprehension skill appears to be hasty rates of speech and students' incompetence to grasp English sounds. She also adds that a slower speech rate could assist learners to understand better, particularly at lower levels. Besides, further ways of enhancing listening skill contain supplying questions connected to the main ideas, and presenting background info as to the topic. Teaching listening skill, particularly for starters, should concentrate on listening practice initially and gradually include speaking practice based on learners' learning progress. Moreover, It is required to contain some methods or strategies of teaching listening in EFL context like Suggestopedia, which is considered being able to make students employ deep breathing, meditation, or progressive relaxation and also Jazz Chant, which is considered being able to make students employ music (Huei-Chun, 1998). It is a mandatory that listening strategies require to be employed as the supplementary of comprehension of listening input (Tyagi, 2013).

\section{METHODOLOGY}

The research design employed in this research article belongs to descriptive. The data were collected from elementary level EFL university students studying in three private universities. The respondents were selected randomly from three private Islamic universities. The participants were 50 elementary level university students. The study took place during the second semester of the 2018/19 school year.

The research instruments employed in this study are questionnaires and interviews. The questionnaire and interview were administered to 50 university students to specify their listening problems. The data of the interview were evaluated and presented in the paper while the data gathered from the questionnaire were analyzed by means of descriptive statistics. Descriptive statistics describes the data gathered from participants (Pollak, 2009). Based upon a research design, this study involved the data analysis of descriptive statistics. In this sense, SPSS 20.0, a Statistical Program for Social Sciences was capitalized to report the perceptions of elementary level EFL students at Islamic University of Kalimantan. In order to analyze the data obtained from the questionnaire, mean $\left(\mathrm{x}^{-}\right)$was used as a statistical technique to find out the rate of 


\section{INTENSIVE JOURNAL \\ http://ojs.uniska-bjm.ac.id/index.php/EJB \\ E-ISSN 2620-4746 \\ April 2020, Vol 3 No.1}

agreement related to the items about listening problems of the students in EFL classrooms. The scorings below were used to compare the means $\left(\mathrm{x}^{-}\right)$of the perspectives specified.

1. Strongly do not agree: $\quad 1.00-1.49$

2. Do not agree: $\quad 1.50-2.49$

3. Not sure: $\quad 2.50-3.49$

4. Agree: $\quad 3.50-4.49$

5. Strongly agree: $\quad 4.50-5.00$

\section{FINDING AND DISCUSSION}

Table 1: Results concerning the problems related to task

\begin{tabular}{|c|l|c|c|}
\hline No & \multicolumn{1}{|c|}{ ITEMS } & Mean $(\overline{\boldsymbol{x}})$ & SD \\
\hline 1 & $\begin{array}{l}\text { Being difficult to do listening tasks, such as filling a } \\
\text { grid, for which I need to draw on specific information } \\
\text { from the text. }\end{array}$ & 3,00 & 1,309 \\
\hline 2 & $\begin{array}{l}\text { Being difficult to do listening tasks for which I need to } \\
\text { combine information to make generalization while } \\
\text { listening to the text. }\end{array}$ & 2,74 & 1,242 \\
\hline 3 & $\begin{array}{l}\text { Being difficult to answer Wh-questions in a listening } \\
\text { task. }\end{array}$ & 2,72 & 1,429 \\
\hline & TOTAL & 2.82 & \\
\hline
\end{tabular}

Note. SD = Standard Deviation

As observed in Table 1, for the 1st item, regarding being difficult to do listening tasks, such as filling a grid, for which I need to draw on specific information from the text, the mean (x) score for this part is 3,00. This score indicates that Item 1 is the most agreed item by the EFL students. The participants are not sure about the item, though.

As it is shown in Table 1, for the 3rd item, regarding being difficult to answer Whquestions in a listening task, the mean (x) score for this part is 2,72. This score indicates that Item 3 is the least agreed item by the EFL students. The participants are not sure about the item, though.

For Item 3, regarding being difficult to do listening tasks for which Ineed to combine information to make generalization while listening to the text, the mean (x) score for this part is 2,74. This score indicates that the participants are not sure about the item. 


\section{INTENSIVE JOURNAL \\ http://ojs.uniska-bjm.ac.id/index.php/EJB \\ E-ISSN 2620-4746 \\ April 2020, Vol 3 No.1}

Related to the problems related to task, the total mean (x) was found 2,82 . This score indicates that the participants are not sure about the problems related to task.

Table 2: Results concerning with effect of the problems

\begin{tabular}{|c|l|c|c|}
\hline No & \multicolumn{1}{|c|}{ ITEMS } & Mean $(\bar{x})$ & $S D$ \\
\hline 4 & $\begin{array}{l}\text { Stopping listening when I have problems in } \\
\text { understanding a listening text. }\end{array}$ & 3.04 & 1.195 \\
\hline 5 & $\begin{array}{l}\text { If I don't arrive at a total comprehension of an oral } \\
\text { text, I feel dis- appointed. }\end{array}$ & 2.78 & 1.314 \\
\hline 6 & $\begin{array}{l}\text { Being difficult to reduce my anxiety before doing } \\
\text { the listening task. }\end{array}$ & 2.70 & 1.298 \\
\hline 7 & $\begin{array}{l}\text { Before doing listening comprehension tasks, I } \\
\text { fear that I cannot understand what I will hear. }\end{array}$ & 2.64 & 1.241 \\
\hline & \multicolumn{1}{|c|}{ TOTAL } & 2.79 & \\
\hline
\end{tabular}

Note. $\mathrm{SD}=$ Standard Deviation

As observed in Table 2, for the $4^{\text {th }}$ item, regarding stopping listening when I have problems in understanding a listening text, the mean $(\mathrm{x})$ score for this part is 3,04 . This score indicates that Item 4 is the most agreed item by the EFL students. The participants are not sure about the item, though.

As it is shown in Table 2, for the $7^{\text {th }}$ item, regarding Before doing listening comprehension tasks, I fear that I cannot understand what I will hear, the mean (x) score for this part is 2,64. This score indicates that Item 7 is the least agreed item by the EFL students. The participants are not sure about the item, though.

For Item 5, regarding If I don't arrive at a total comprehension of an oral text, I feel disappointed, the mean (x) score for this part is 2,78. This score indicates that the participants are not sure about the item.

For Item 6, regarding being difficult to reduce my anxiety before doing the listening task, the mean (x) score for this part is 2,70. This score indicates that the participants are not sure about the item.

Related to the affect of the listening problems, the total mean (x) was found 2,79. This score indicates that the participants are not sure about the affect of the listening comprehension problems. 
INTENSIVE JOURNAL

http://ojs.uniska-bjm.ac.id/index.php/EJB

E-ISSN 2620-4746

April 2020, Vol 3 No.1

Table 3 : Results pertaining to the problems related to context

\begin{tabular}{|c|l|c|c|}
\hline No & \multicolumn{1}{|c|}{ ITEMS } & Mean $(\bar{x})$ & $S D$ \\
\hline 8 & $\begin{array}{l}\text { Unclear sounds resulting from a poor-quality CD-player } \\
\text { interfere with my listening comprehension. }\end{array}$ & 3.28 & 1.341 \\
\hline 9 & $\begin{array}{l}\text { Unclear sounds resulting from poor acoustic conditions } \\
\text { of the class- room interfere with my listening } \\
\text { comprehension. }\end{array}$ & 2.82 & 1.224 \\
\hline & TOTAL & 3,05 & \\
\hline
\end{tabular}

Note. SD = Standard Deviation

As observed in Table 3, for the 39th item, regarding unclear sounds resulting from a poor-quality $C D$-player interfere with my listening comprehension, the mean ( $\mathrm{x})$ score for this part is 3,28 . This score indicates that Item 8 is the most agreed item by the EFL students. The participants are not sure about the item, though.

As it is shown in Table 3, for the 9th item, regarding unclear sounds resulting from poor acoustic conditions of the classroom interfere with my listening comprehension, the mean $(\mathrm{x})$ score for this part is 2,82 . This score indicates that Item 9 is the least agreed item by the EFL students. The participants are not sure about the item, though.

Related to the problems related to context, the total mean (x) was found 3,05. This score indicates that the participants are not sure about the problems related to context.

\section{CONCLUSION}

If students don't bother to learn how to listen then they never learn how to speak as well. Listening is considered important in EFL classroom as it supplies the learner with input. If strategies are not develeoped to aid the learners to comprehend the needed input, then learning doesn't occur. Listening skill has been ignored in EFL context, as well as being underestimated in research literature when compared to other skills of English. However, listening is vital in language learning in that it provides input for the learner. Without understanding inputs, students can't learn anything.

Listening comprehension is clearly the weakest skill of EFL students who encounter different kinds of listening problems. This study is conducted with the aim of 


\section{INTENSIVE JOURNAL \\ http://ojs.uniska-bjm.ac.id/index.php/EJB \\ E-ISSN 2620-4746 \\ April 2020, Vol 3 No.1}

discovering the elements causing the students' listening problems. The research results have routed us to reach at the following conclusions, students find it difficult to comprehend the listening concerning with the problems related to task, concerning with effect of the problems, and concerning with the problems related to context

\section{REFERENCES}

Al-Alwan, A., Asassfeh, S., \& Al-Shboul, Y. (2013). EFL Learners' Listening Comprehension and Awareness of Metacognitive Strategies: How Are They Related? International Education Studies, 6(9), p31.

Al-Tiyabi, M.S. (2014). Need Analysis for EFL Listening Skills at the ELL: English for Specific Purposes World. 43(15), 1-32.

Anderson, J. R. (1985). Cognitive psychology and its implications (2nd eds.). New York: W. H. Freeman.

Andrade, M. E. A. D. (2006). Improving How Listening Skills are Taught in the EFL Classroom: Guidelines to Producing Better Speakers of the English Language.

Bennui, P. (2007). A survey on first-year students' opinions concerning causes of their low performance in listening in the English II course at Thaksin University, Phatthalung.

Chen, A. (2010). Effects of listening strategy training for EFL adult listeners. The Journal of Asia TEFL, 7(1), 135-169.

Croom, Helm Cross, D. (1998). Teach English, Oxford: Oxford University Press.

Dey, S. C. (2014). Authentic Input to Motivate Learners to Develop Listening Skill: Benefits, Drawbacks of Using Podcast. M.A. Thesis. BRAC University: Bangladesh.

Field, J. (2008b). Revising segmentation hypotheses in first and second language listening. System, 36(1), 35-51.

Ghaderpanahi, L. (2012). Using Authentic Aural Materials to Develop Listening Comprehension in the EFL Classroom. English Language Teaching. 5(6), 146153.

Goh, C. (2000). A cognitive perspective on language learners' listening comprehension problems. System, 28(1), 55-75.

Goh, C., \& Taib, Y. (2006). Metacognitive instruction in listening for young learners. ELT Journal, 60(3), 222-232.

Graham, S. \& Macaro, E. (2008). Strategy instruction in listening for lower-intermediate learners of French. Language Learning, 58(4), 747-783.

Hamouda, A. (2013). An Investigation of Listening Comprehension Problems Encountered by Saudi Students in the EL Listening Classroom. International Journal of Academic Research in Progressive Education and Development. 2(2), 113-155.

Helgesen, M. (2003). Listening in Practical Language Teaching, edited by David Nunan. Hichem, B. (2013). An Investigation on Listening Challenges facing EFL Learners. M.A. Thesis. Mohammed Khider University of BISKRA: Algeria. 


\section{INTENSIVE JOURNAL \\ http://ojs.uniska-bjm.ac.id/index.php/EJB \\ E-ISSN 2620-4746 \\ April 2020, Vol 3 No.1}

Huei-Chun, T. (1998). A Study of EFL Listening Comprehension Strategies. Eric. 1-19.

Liu, N. F. (2002). Processing problems in L2 listening comprehension of university students in Hong Kong. (Doctoral dissertation). Retrieved on June 3, 2014 from ProQuest Dissertations \& Theses database. (UMI No. 3074191).

Nowrouzi, S., Tam, S. S., Zareian, G., \& Nimehchisalem, V. (2015). Iranian EFL Students' Listening Comprehension Problems. Theory and Practice in Language Studies, 5(2), 263-269.

Rivers, W. 1984. 'What practitioners say about listening: Research implications for the classroom' in R. A. Gilman and L. M. Moody. 1984. Foreign Language Annals 17/4: 331-4.

Solak, E., \& Altay, F. (2014). Prospective EFL Teachers' Perceptions of Listening Comprehension Problems in Turkey. Journal of International Social Research, 7(30), 190-198.

Tyagi, B. (2013). Listening: An Important Skill and Its Various Aspects. The Criterion: An International Journal in English. 12, 1-8.

Ulum, Ömer Gökhan. (2015). Listening: The Ignored Skill in EFL Context. International Journal of Humanities Social Sciences and Education (IJHSSE), 2(5) 257-270.

Vandergrift, L. (1999). Facilitating Second Language Listening Comprehension: Acquiring Successful Strategies. ELT Journal. 53(3), 168-176.

Vandergrift, L. (2003). Orchestrating strategy use: Towards a model of the skilled L2 listener. Language Learning, 53(3), 463-496.

Y1ldirım, S. (2013). A Comparison of EFL Teachers' and Students' Perceptions of Listening Comprehension Problems and Teachers' Reported Classroom Practices. M.A. Thesis. Bilkent University: Ankara. 